The Labore Journal of Economics

11 : 2 (Winter 2006) pp. 123-139

\title{
The Disappearing Calendar Anomalies in the Singapore Stock Market
}

\author{
Wing-Keung Wong ${ }^{*}$, Aman Agarwal ${ }^{* * *}$ and Nee-Tat Wong
}

\begin{abstract}
This paper investigates the calendar anomalies in the Singapore stock market over the recent period from 1993-2005. Specifically, changes in stock index returns are examined surrounding January (the January effect), on different days of the week (the day-of-the-week effect), around the turn of the month (the turn-of-the-month effect) and before holidays (the pre-holiday effect). The findings reveal that these anomalies have largely disappeared from the Singapore stock market in recent years. The disappearance of these anomalies has important implications for the efficient market hypothesis and the trading behavior of investors.
\end{abstract}

JEL Code: C10, G12, G15

Keywords: Calendar anomalies, January effect, day-of-the-week effect, turnof-the-month effect, pre-holiday effect.

\section{Introduction}

Extensive evidence has been provided on the existence of calendar anomalies in the US and many other countries. The main calendar anomalies are the January effect, the day-of-the-week effect, the turn-ofthe-month effect and the holiday effect. Despite the mounting evidence, the reasons for these anomalies have remained largely unknown. These anomalies are of particular interest because their existence violates the weak form of market efficiency. The weak form of market efficiency

\footnotetext{
* Associate Professor of Economics, Department of Economics, National University of Singapore, Singapore.

** Professor of Finance \& Director (Offg), Indian Institute of Finance, Ashok Vihar, Delhi, India

ANU Distinguished Visiting Research Scholar, The Australian National University, National Graduate School of Management, Canberra ACT, Auastralia

${ }^{* * *}$ Lecturer, The Tourism Academy at Sentosa, Temasek Polytechnic, Singapore.
} 
implies that in an efficient stock market, stock prices fully reflect all available information so that investors make only normal profits. Thus, investors cannot make abnormal returns by exploiting these anomalies. Given that these anomalies are relatively easy to exploit, they should have weakened or disappeared over time. However, most previous studies have not explicitly examined how these anomalies change over time.

In the Singapore stock market, various researchers have been documenting the existence of calendar anomalies. The main objective of this study is to re-examine the calendar anomalies in the Singapore market using an updated data set up to December 2005. Through this study, we found that the anomalies in the Singapore market have weakened recently.

The rest of the paper proceeds as follows. Section II contains the literature review while Section III discusses the background and development of the Singapore stock market. Section IV describes the data and methodology. Section $\mathrm{V}$ examines the individual calendar anomalies, while Section VI concludes.

\section{Literature Review}

\section{January Effect}

The January effect describes the phenomenon that stock returns in January are on average higher than for the other months. In the US stock market, the January effect was first documented by Rozeff and Kinney (1976). A later study by Keim (1983) showed that the January effect is largely confined to stocks of small firms and to the first few trading days in January.

The January effect has been observed in other countries. Gultekin and Gultekin (1983) investigated the January effect in seventeen major industrialized countries and found unusually high January returns in most of the countries studied (specifically, Australia, Belgium, Canada, Denmark, Germany, Japan, Netherlands, Norway, Spain, Sweden and Switzerland).

In the Singapore market, Wong and Ho (1986) found that the mean daily return in January is significantly higher than the returns in other months over the period 1975-1984. In addition, they found no significant differences between the mean returns on the last five trading days and those of the first five trading days of the year, a result inconsistent with the US evidence. Further evidence on the January effect in the Singapore market is provided by Agarwal and Rivoli (1989), Lee (1992) and Chan et al (1996). 


\section{Day-of-the-Week Effect}

The day-of-the-week effect refers to the observation that stock returns are not equal across the days of the week. In particular, the mean return on Monday is negative and generally the lowest while the mean return on Friday is positive and generally the highest. Extensive evidence of the day-of-the-week effect has been documented in the US stock market, for example, French (1980), Gibbons and Hess (1981), Keim and Stambaugh (1984), Smirlock and Starks (1986), Lakonishok and Smidt (1988), Abraham and Ikenberry (1994) and Wang et al (1997). More recently, Mehdian and Perry (2001) found that the Monday effect has significantly declined and detected a reversal of the Monday effect in large capitalization stocks (represented by the S\&P 500, the Dow Jones Composite and the NYSE Composite) in recent years.

The day-of-the-week effect has been widely reported in other countries. In Singapore, Wong and Ho (1986) documented a weekly seasonal pattern of stock returns over the period 1975-1984. Subsequent studies by Condoyanni et al (1987), Aggarwal and Rivoli (1989), Wong et al (1992) and Chan et al (1996) provide further evidence of the day-of-the-week effect in the Singapore market.

\section{Turn-of-the-Month Effect}

The turn-of-the-month effect refers to the unusually high stock returns at the turn of the month defined as the period from the last trading day of the previous month to the first three trading days of the current month. Using the Dow Jones Industrial Average (DJIA) index from 18971986, Lakonishok and Smidt (1988) found that the mean return on the turn-of-the-month trading days is about eight times higher than on other trading days. Extending the analysis to other countries, Cadsby and Ratner (1992) found that the turn-of-the-month effects are present in Australia, Canada, Switzerland, UK and West Germany but not in France, Hong Kong, Italy or Japan.

In Singapore, a study by Tan and Wong (1996) found a significant turn-of-the-month effect. They showed that the mean stock return on turnof-month trading days is significantly higher than other trading days, over the period 1975-1994.

\section{Holiday Effect}

The holiday effect refers to the observation that the mean stock return is higher on the trading day immediately preceding holidays (pre- 
holidays) than on other trading days. Ariel (1990) examined daily returns on the CRSP equally-weighted and value-weighted indices of NYSE and AMEX stocks from 1963-82 and found that the mean return on pre-holidays is significantly higher than the remaining trading days. Similar results are reported by Pettengill (1989) and Kim and Park (1994) who independently analyzed the US stock market over different time periods.

Cadsby and Ratner (1992) found that the holiday effects are significant in Australia, Canada, Hong Kong, Japan and US but not in France, Italy, Switzerland, UK and West Germany. They also found that, with the exception of Hong Kong, the countries exhibiting holiday effects do so before their own local holidays.

In the Singapore market, Tan and Wong (1996) showed that stock returns are significantly higher on pre-holidays than on other trading days in the period 1975-94 using the SES All Singapore Index. However, subsequent studies by Chan et al (1996) and others found that the holiday effect in Singapore is mainly a Chinese New Year effect as only the Chinese New Year has a significant holiday effect; the pre-holiday returns for the other holidays are not statistically significant.

\section{Background and Developments on the Singapore Stock Market}

The Singapore stock market, known as the Stock Exchange of Singapore (SES), is one of the fastest growing emerging stock markets in South East Asia. Approved by the Minister for Finance in Singapore under the provisions of the Security Industry Act, the Stock Exchange of Singapore Limited was incorporated on May 24, 1973 and commenced its operations on June 4,1973 . It is the only corporate body to operate a stock market of a security exchange in Singapore. Thereafter, following the merger of two established and well-respected financial institutions - the SES and the Singapore International Monetary Exchange (SIMEX) - the Singapore Exchange Limited (SGX) was inaugurated on December 1, 1999 to operate the stock market and futures market in Singapore. As of December 2005, the SGX listed 663 companies with a market capitalization of over S\$ 427.9 billion. As of December 2005, the companies with the largest capitalization included Singapore Telecommunications, DBS Group (a financial service group) and United Overseas Bank. For 2005, the total turnover was nearly 181.5 billion shares valued at over S\$ 200 billion.

Since the establishment of the Singapore capital market, various reforms have been implemented towards the development of a modern and efficient capital market including: revised tax systems, relaxation of exchange 
controls, privatization of publicly owned enterprises, removal of restrictions on repatriation of profits and, most importantly, the opening of the share market to foreign investors. These policies led Singapore to achieve remarkable development in its stock market, which then became one of the most important markets in the region.

\section{Data and Methodology}

The Straits Times Index, a market-capitalization weighted index of 55 (actively-traded) large capitalization stocks, from Datastream International covering the period from January 1993 to December 2005 is used in our study. To examine the anomalies, we analyze the entire period from January 1993 to December 2005 and further analyze the sub-periods: January 1, 1993 - December 31, 1997 (pre-crisis Period), and January 1, 1998 - December 31, 2005 (post-crisis Period) with the 1997 Asian Financial Crisis being a cut-off point to separate these sub-periods. The daily log-return used in our study is:

$$
R_{t}=\ln \left(P_{t} / P_{t-1}\right)
$$

where $P_{t}$ is the closing value of stock index on day $t$.

As stock returns are well-known to be heteroscedastic, we incorporate the GARCH $(1,1)$ model (Brooks and Ragunathan, 2003) into the mean equation to test for the January effect for the returns, such that:

$$
\begin{aligned}
& R_{t}=\sum_{i=1}^{12} b_{i} D_{i t}+\varepsilon_{t} \\
& \varepsilon_{t} / \psi_{t-1} \sim N\left(0, h_{t}\right) \text { and } h_{t}=\alpha_{0}+\alpha_{1} \varepsilon_{t-1}^{2}+\beta_{1} h_{t-1}
\end{aligned}
$$

where $R_{t}$ is the daily return on day $t$ defined in (1), $D_{i t}$ is a dummy variable to measure the monthly effects and is set equal to one if the day is in month $i$ and zero otherwise, the coefficients $b_{i}$ measure the mean daily return of the respective month, $\alpha_{1}$ measures the $\mathrm{ARCH}$ effect and $\beta_{1}$ measures the GARCH effect of the volatility. If the value of the mean return is about the same for each month, then the estimates $b_{1}$ through $b_{12}$ will be close to zero and the F-statistic will be insignificant. 
Similarly, we adopt the following model to test for the day-of-theweek effect:

$$
\begin{aligned}
& R_{t}=\sum_{i=1}^{5} b_{i} D_{i t}+\varepsilon_{t}, \\
& \varepsilon_{t} / \psi_{t-1} \sim N\left(0, h_{t}\right) \text { and } h_{t}=\alpha_{0}+\alpha_{1} \varepsilon_{t-1}^{2}+\beta_{1} h_{t-1}
\end{aligned}
$$

where $R_{t}$ is the daily return on day $t$ defined in (1), $D_{i t}$ is a dummy variable which is equal to one if the day is a weekday $i$ and zero otherwise, and the coefficient $b_{i}$ represents the expected return for the corresponding day $i$ of the week. If the mean return is similar for each day of the week, the estimates $b_{1}$ through $b_{5}$ will be close to zero and the F-statistic should be insignificant.

To test for the Turn-of-the-Month Effect and the Holiday Effect, we simply apply the simple t-test for two independent samples.

\section{Empirical Findings and Interpretation}

\section{Testing for the January Effect}

The January effect in the Singapore market has been found in the literature to be significantly positive relative to all other months, inferring that January attains the highest return on average. Different from the findings in the literature, our findings in Panel A of Table 1 first show that the mean daily return in January is positive but insignificant in the pre-crisis period of 1993-97, implying that though the mean daily return in January is higher than most of the other months in the pre-crisis period, the differences are not significant. In addition, our findings contradict the findings in the literature that the mean daily returns of the Straits Times Index are negative in the entire period as well as in the post-crisis period. This leads us to conclude that the January effect changes from positive in the pre-crisis to negative in the post-crisis period but the differences are not significant in either period. 


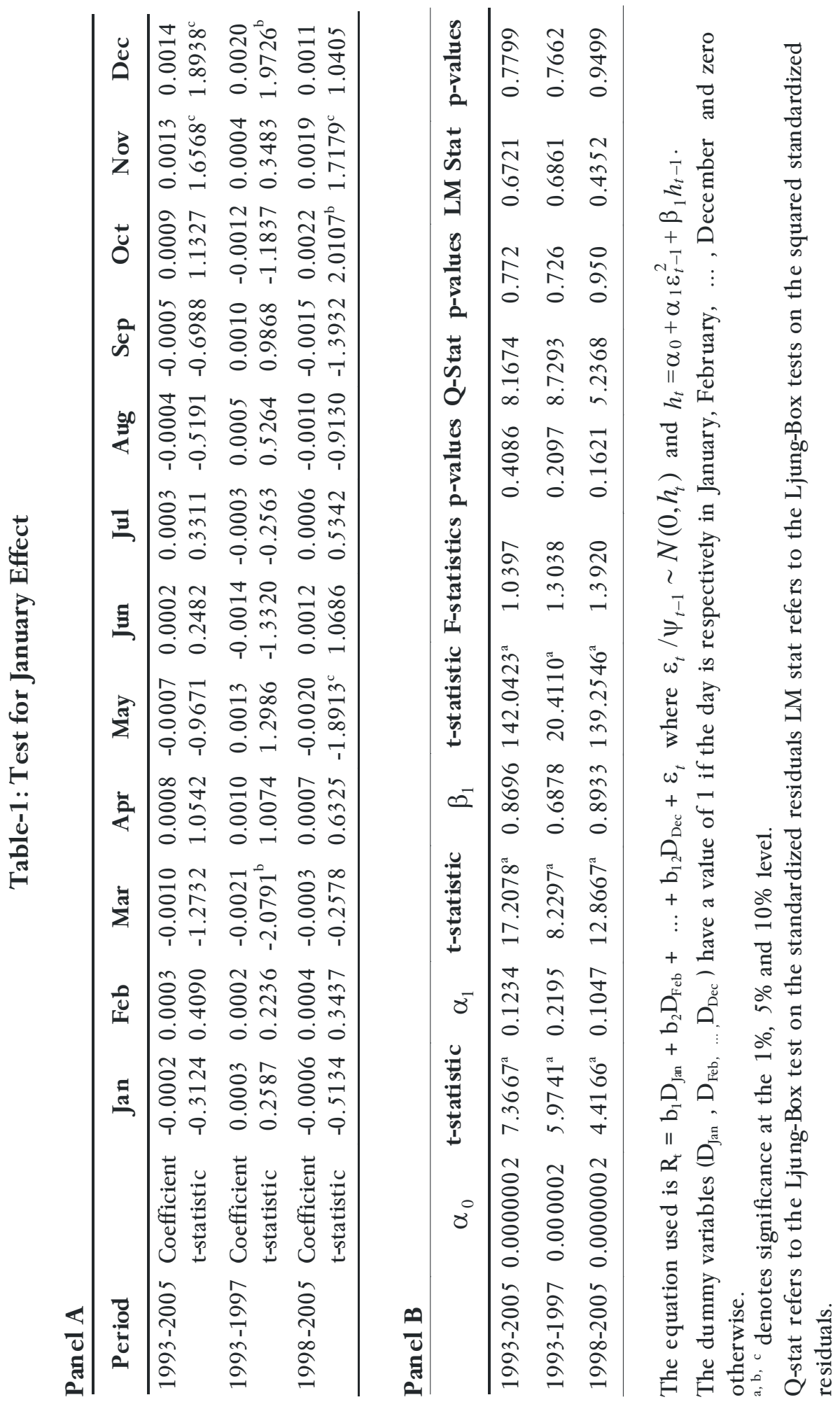


In addition, Pane1 $\mathrm{B}$ of Table-1 shows that both ARCH and GARCH coefficients are highly significantly positive in the full period and both subperiods, reflecting time dependence in the process and volatility shocks which are allowed to persist over time. The diagnostics check displayed in the Table exhibits the Ljung-Box tests on the standardized residuals (Q-stat) and on the squared standardized residuals (LM stat). As all the p-values are larger than conventional levels, we conclude that the fitted model is adequate and successful in capturing the dynamics in the first as well as second moments of the return series, which in turn implies that our analysis and conclusions are appropriate.

\section{Testing for the Day-of-the-Week Effect}

Table-2 reveals a weekly pattern of stock returns. As can be seen from Panel A, the results show that the mean Monday returns are negative in the full period as well as in the two sub-periods, as indicated by the negative coefficients for Monday. Additionally, the mean returns tend to increase as the week progresses with the highest returns on the last day of the week. This may explain why the mean returns of the first two days of the week are consistently lower than those of the last three days of the week. To test the equality of mean returns across the days of the week, the F-test was used. In the full period and in the pre-crisis period, the Fstatistics are significant at the $5 \%$ level. However, in the post-crisis period, the F-statistics are insignificant. This shows that the day-of-the-week effect may no longer exist in the Singapore market. 
The Disappearing Calendar Anomalies in the Singapore Stock Market

Table-2: Test for day-of-the-week effect

Panel A

\begin{tabular}{llcccccc}
\hline Period & & Mon & Tue & Wed & Thu & Fri & F-stat \\
\hline $1993-2005$ & Coefficient & -0.0012 & 0.0002 & 0.0008 & 0.0002 & 0.0009 & $2.4571^{\mathrm{b}}$ \\
& t-statistic & $-2.3914^{\mathrm{b}}$ & 0.3973 & 1.6340 & 0.3499 & $1.9017^{\mathrm{c}}$ & {$[0.0313]$} \\
$1993-1997$ & Coefficient & -0.0013 & 0.0001 & 0.0014 & -0.0001 & 0.0007 & $1.9317^{\mathrm{b}}$ \\
& t-statistic & $-1.9740^{\mathrm{b}}$ & 0.0917 & $2.1105^{\mathrm{b}}$ & -0.2051 & 1.1212 & {$[0.0863]$} \\
$1998-2005$ & Coefficient & -0.0011 & 0.0003 & 0.0005 & 0.0004 & 0.0011 & 1.1724 \\
& t-statistic & -1.6133 & 0.4068 & 0.6550 & 0.5252 & 1.5457 & {$[0.3203]$} \\
\hline
\end{tabular}

Panel B

\begin{tabular}{lccccc}
\hline Period & $\alpha_{0}$ & $\alpha_{1}$ & $\beta_{1}$ & Q-Stat & LM Stat \\
\hline \multirow{2}{*}{$1993-2005$} & $0.0000002^{\mathrm{a}}$ & $0.1188^{\mathrm{a}}$ & $0.8747^{\mathrm{a}}$ & 5.6495 & 1.1463 \\
& $(7.3492)$ & $(17.3009)$ & $(149.1192)$ & {$[0.342]$} & {$[0.3334]$} \\
\multirow{2}{*}{$1993-1997$} & $0.0000009^{\mathrm{a}}$ & $0.2125^{\mathrm{a}}$ & $0.7005^{\mathrm{a}}$ & 2.5640 & 0.5230 \\
& $(5.7597)$ & $(8.0109)$ & $(20.9601)$ & {$[0.767]$} & {$[0.7590]$} \\
$1998-2005$ & $0.0000001^{\mathrm{a}}$ & $0.0999^{\mathrm{a}}$ & $0.8981^{\mathrm{a}}$ & 4.6587 & 0.9672 \\
& $(4.2093)$ & $(13.0743)$ & $(148.4801)$ & {$[0.459]$} & {$[0.4365]$} \\
\hline
\end{tabular}

The regression equation used is $\mathrm{R}_{\mathrm{t}}=\mathrm{b}_{1} \mathrm{D}_{\text {Mon }}+\mathrm{b}_{2} \mathrm{D}_{\text {Tue }}+\ldots+\mathrm{b}_{5} \mathrm{D}_{\mathrm{Fri}}+\varepsilon_{t} \quad$ where $\varepsilon_{t} / \psi_{t-1} \sim N\left(0, h_{t}\right)$ and $h_{t}=\alpha_{0}+\alpha_{1} \varepsilon_{t-1}^{2}+\beta_{1} h_{t-1}$.

The dummy variables $\left(\mathrm{D}_{\text {Mon, }}, \mathrm{D}_{\text {Tue, ... }}, \mathrm{D}_{\text {Fri }}\right)$ have a value of 1 if the day is respectively Monday, Tuesday, Wednesday, .., Friday and zero otherwise.

a, b, c denote significance at the $1 \%, 5 \%$ and $10 \%$ level respectively.

The parentheses figures are the t-statistics.

Q-stat refers to the Ljung-Box test on the standardized residuals LM stat refers to the Ljung-Box tests on the squared standardized residuals.

The bracketed figures are the p-values of the F-statistics, Q-statistics and LM statistics.

Similar to the situation in testing the Monthly effect, Panel B of Table-2 confirms the existence of both ARCH and GARCH effects in the full period as well as in both sub-periods and the diagnostics check infers that the fitted model is adequate and successful in capturing the dynamics in the first as well as second moments of the return series, which in turn implies that our analysis and conclusion are correct. 


\section{Testing for the Turn-of-the-Month Effect}

Following previous studies, the turn-of-the-month is defined as the period from the last trading day of the previous month to the first three trading days of the current month. Table-3 compares the mean returns of turn-of-the-month trading days with other trading days. It can be seen from the Table that turn-of-the-month trading days earn higher returns, on average, than other trading days for the full period and two subperiods.

Table 3: Test for turn-of-the-month effect

\begin{tabular}{llccc}
\hline Period & & Mean & Std Dev & Obs \\
\hline 1993-2005 & Turn-of-the-month trading days & 0.0017 & 0.0130 & 622 \\
& Other trading days & -0.0002 & 0.0129 & 2768 \\
& t-stat & $3.2928^{\mathrm{a}}$ & & \\
$1993-1997$ & Turn-of-the-month trading days & 0.0022 & 0.0098 & 239 \\
& Other trading days & -0.0003 & 0.0107 & 1064 \\
& t-stat & $3.2880^{\mathrm{a}}$ & & \\
$1998-2005$ & Turn-of-the-month trading days & 0.0015 & 0.0147 & 383 \\
& Other trading days & -0.0001 & 0.0141 & 1704 \\
& t-stat & $1.8898^{\mathrm{c}}$ & & \\
\hline
\end{tabular}

a, b, c denotes significance at the $1 \%, 5 \%$ and $10 \%$ level respectively

However, a one-tailed t-test of the difference of means between turn-of-the-month trading days and other trading days detected a significant decline of the turn-of-the-month effect from the pre-crisis period to the post-crisis period. These results show that the turn-of-themonth effect exists in the pre-crisis period but has diminished significantly thereafter.

\section{Testing for the Holiday Effect}

For the purpose of this study, a holiday is defined as a day on which the stock market is closed as a result of a public holiday. This definition follows the studies by Pettengill (1989) and Ariel (1990). Table4 shows that the mean returns on pre-holidays are higher than that of other trading days for the full period and two sub-periods. The standard deviation of returns of pre-holidays is higher than those of other days so we infer that higher returns are accompanied by higher risk for the Straits Times Index. 
Table 4: Test for holiday effect

\begin{tabular}{llccc}
\hline Period & & Mean & Std Dev & Obs \\
\hline $1993-2005$ & Pre-holidays & 0.0025 & 0.0139 & 111 \\
& Other trading days & 0.00011 & 0.0129 & 3279 \\
& t-stat & $1.8955^{\mathrm{c}}$ & & \\
$1993-1997$ & Pre-holidays & 0.0032 & 0.0133 & 41 \\
& Other trading days & 0.00005 & 0.0105 & 1262 \\
& t-stat & $1.8694^{\mathrm{c}}$ & & \\
$1998-2005$ & Pre-holidays & 0.0021 & 0.0143 & 70 \\
& Other trading days & 0.00015 & 0.0142 & 2017 \\
& t-stat & 1.1072 & & \\
\hline
\end{tabular}

a, b, c denote significance at the $1 \%, 5 \%$ and $10 \%$ level respectively

A one-tailed t-test for the differences of the means between preholidays and other trading days is significant in the full period in the precrisis period. However, in the post-crisis period, the t-statistic is insignificant. This shows that the holiday effect has declined and over time and it may no longer exist in the Singapore stock market.

\section{Discussion and Conclusions}

This study re-examines the calendar anomalies - January effect, dayof-the-week, turn-of-the-month effect and holiday effect in the Singapore stock market. In the pre-crisis period, our study generally supports previous findings of these anomalies in the Singapore market. However, analysis in the post-crisis period shows that these anomalies have significantly declined or disappeared. Our results also reveal for the first time that there has been a reversal, though insignificant, of the January effect over time since the Asian financial crisis.

The disappearance of the calendar anomalies implies that investors may no longer be able to generate abnormal returns by capitalizing on these anomalies. This is likely to be due to investors increasingly being aware and taking advantage of the anomalies which has priced away any advantage. In addition, high volatility combined with economic and financial instability after the 1997 Asian financial crisis may have resulted in the elimination of calendar anomalies. Moreover, the arrival of bad information such as the global economic downturn, terrorist attacks, the war in Iraq, and the SARS outbreak, have caused uncertainty that may have altered uninformed 
investors' decisions. These may explain the absence of the calendar effect in the Singapore stock market.

Our findings support the argument that most anomalies will diminish and eventually disappear after their discovery as more and more investors exploit this effect. For example, after discovering the January effect, investors who expect the stock price to appreciate in January will then purchase before January and sell at the end of January. This will drive up the stock prices before January and push down the prices at the end of January, and result in the diminishing or even disappearance of the January effect. In addition, the calendar anomaly results in our paper can assist investors in their investment decision-making in the Singapore stock market. Disappearance of calendar anomalies would also lend support to the conjecture that Singapore's stock market satisfies the weak-form of the Efficient Market Hypothesis. While satisfactory clarifications have been found for such anomalies as the small firm in January (Keim, 1983), bookto-market (Fama and French, 1992), (Reinganum, 1988) and reversals (Debondt and Thaler, 1985), (Chopra, Lakonishok and Ritter, 1992) fuller explanations for the failure of the efficient markets hypothesis have ranged from risk premia (Fama and French, 1993) an illiquidity premium or inefficient markets (Lakonishok, Shliefer and Vishney, 1995).

We note that it is well-known that stock returns are heteroscedastic and hence a GARCH model is used to model the returns (Brooks and Ragunathan 2003). Our findings show that both ARCH and GARCH coefficients are highly significantly positive in the full period as well as in both sub-periods for the models of the monthly effects and the day-of-theweek effect; this reflects time dependence in the process and persistence of volatility shocks over time. This persistence captures the propensity of returns to cluster over time and explains the non-normality and nonstability of empirical asset return distribution. The diagnostic check concludes that the fitted model is adequate and successful in capturing the dynamics in the first as well as second moments of the return series, which in turn implies that our analysis and conclusions are appropriate.

It is also well-known that the error term for the return is not normal, (Clark 1973). However, the regression equation used in this paper is still valid by the central limit theorem. ${ }^{1}$

\footnotetext{
${ }^{1}$ Another approach would be the robust Bayesian sampling estimators (Matsumura et al 1990 and Wong and Bian 2000). Other alternatives include using other advanced statistics to improve the test, (Wong and Miller 1990, Tiku et al 2000, Fong and Wong 2006).
} 
The disappearance of the calendar anomalies from the Singapore markets suggests that the Singapore (and probably other regional) markets are becoming more efficient, due mainly to more knowledgeable and experienced investors, advances in information technology and communications, lower cost of information, etc. Is this a global trend towards market efficiency? The best that can be said for now is that as with most things in life, only time will tell. 


\section{References}

Abraham, A. and Ikenberry, D.L., 1994, The Individual Investor and the Weekend Effect, Journal of Financial and Quantitative Analysis, 20, 263-77.

Agarwa1, J.D. and Aman Agarwal, 2001, "Liberalization of Capital Flows, Banking System \& Trade: Focus on Crisis Situations”, International Review of Comparative Public Policy titled "International Financial Systems and Stock Volatility" Volume 13, pp. 151-212. Invited to present at 18th International Conference of Finance at Namur, Belgium (25th-28th June 2001), at Florida International University, Florida, USA (26th September 2001), discussed with FIU Finance faculty at Luncheon presentation, Florida, USA (27th September 2001), at Pontific Catholic University of Rio de Janerio, Rio de Janerio, BRAZIL (22rd October 2001). Also discussed at a few conferences in the USA and UK in April and May 2001.

Agarwal, J.D. and Aman Agarwa1, 2004, "Globalization and International Capital Flows"; Ananya, Journal of National Institute of Financial Management (Invited Paper), 2004 (forthcoming issue); Invited to deliver the Keynote Address at the Two day National Conference on "Globalization - Decadal Indian Experience", organized by ATMA MAYYIL and the Institute of Technology, Kannur University, Kerela, Indiaon $17^{\text {th }}$ January $2004(12: 00-14: 30)$.

Agarwal, J.D., 2004, "Volatility of International Financial Markets: Regulation and Financial Supervision”, Finance India, XVIII No 1, March 2004; Invited to be delivered as the Keynote Speech at the 4th International Conference in Finance, organized by Faculty of Administration \& Economics, University of Santiago de Chile, Val de Mir, CHILE, 7th January 2004.

Agarwal, J.D., 2005, "Literature in Finance - Vol III : Financial Systems and Markets", IIF Publications, Delhi.

Agarwa1, R. and Rivoli, P., 1989, Seasonal and Day-of-the-Week Effects in Four Emerging Stock Markets, Financial Review, 24, 541-50.

Arie1, R.A., 1990, High Stock Returns before Holidays: Existence and Evidence on Possible Causes, Journal of Finance, 45, 1611-26. 
Broll, U., Wah1, J.E. and Wong, W.K., 2006, Elasticity of Risk Aversion and International Trade, Economic Letters, (forthcoming).

Brooks, R.D. and Ragunathan, V., 2003, Returns and Volatility on the Chinese Stock Markets, Applied Financial Economics, 13, 747-752

Cadsby, C.B. and Ratner, M., 1992, Turn-of-Month and Pre-Holiday Effects on Stock Returns: Some International Evidence, Journal of Banking and Finance, 16, 497-509.

Chan, M.W.L., Khanthavit, A. and Hugh, T., 1996, Seasonality and Cultural Influences On Four Asian Stock Markets, Asia Pacific Journal of Management, 13, 1-24.

Chopra, Navin, Josef Lakonishok, and Jay Ritter, 1992, Measuring Abnormal performance: Do Stocks Overreact? Journal of Financial Economics, $31,235-68$.

Clark, P.K., 1973, A Subordinate Stochastic Process Model with Finite Variance for Speculative Prices, Econometrica, 41 (1), 135-55.

Condoyanni, L., O'Hanlon, J. and Ward, C.W.R., 1987, Day of the Week Effects on Stock Returns: International Evidence, Journal of Business Finance and Accounting, 14, 159-74.

DeBondt, Werner and Richard Thaler, 1985, Does the Stock Market Overreact? Journal of Finance, 40, 793-805.

Fama, Eugene and Kenneth French, 1992, The Cross Section of Expected Stock returns, Journal of Finance 47, 427-65.

Fama, Eugene and Kenneth French, 1993, Common Risk Factors in the returns on Stocks and Bonds, Journal of Financial Economics, 33, 3-56.

Fong, W.M. and Wong, W.K., 2006, The Modified Mixture of Distributions Mode1: A Revisit, Annals of Finance, 2(2), 167 - 178.

Fong, W.M., Wong, W.K. and Lean, H.H., 2005, International Momentum Strategies: A Stochastic Dominance Approach. Journal of Financial Markets, 8, 89-109.

French, K.R., 1980, Stock Returns and the Weekend Effect, Journal of Financial Economics, 8, 55-69. 
Gibbons, M. and Hess, P., 1981, Day of the Week Effects and Asset Returns, Journal of Business, 54, 579-96.

Gultekin, M.N. and Gultekin, N.B., 1983, Stock Market Seasonality: International Evidence, Journal of Financial Economics, 12, 469-481.

Keim, D.B. and Stambaugh, R.F., 1984, A Further Investigation of the Weekend Effect in Stock Returns, Journal of Finance, 39, 819-40.

Keim, D.B., 1983, Size-Related Anomalies and Stock Returns Seasonality: Further Empirical Evidence, Journal of Financial Economics, 12, $13-32$.

Kim, C.W. and Park, J., 1994, Holiday Effects and Stock Returns: Further Evidence, Journal of Financial and Quantitative Analysis, 29, 145-157.

Lakonishok, J. and Smidt, S., 1988, Are Seasonal Anomalies Real? A NinetyYear Perspective, Review of Financial Studies, 1, 403-25.

Lakonishok, Josef, Andrei Schleifer, and Robert Vishney, 1995, Contrarian Investment, Extrapolation and Risk, Journal of Finance 50, 541-578.

Lee, I., 1992, Stock Market Seasonality: Some Evidence from the PacificBasin Countries, Journal of Banking and Finance, 19, 199-210.

Matsumura, EM, Tsui, K.W. and Wong, W.K., 1990, An Extended Multinomial-Dirichlet Mode1 for Error Bounds for Dollar-Unit Sampling, Contemporary Accounting Research, 6(2-I), 485-500.

Mehdian, S. and Perry, M.J., 2001, The Reversal of the Monday Effect: New Evidence from US Equity Markets, Journal of Business Finance \& Accounting, 28, 1043-1065.

Pettengill, G.N., 1989, Holiday Closings and Security Returns, Journal of Financial Research, 12, 57-67.

Reinganum, Marc, March-April, 1988, The Anatomy of a Stock Market Winner, Financial Analysts' Journal, 272-84.

Rozeff, M.S. and Kinney, Jr.W.R., 1976, Capital Market Seasonality: The Case of Stock Returns, Journal of Financial Economics, 3, 379-402.

Smirlock, M. and Starks, L., 1986, Day-of-the-Week and Intraday Effects in Stock Returns, Journal of Financial Economics, 17, 197-210. 
Tan, R. and Wong, N.T., 1996, Calendar Anomalies In The Singapore Stock Market, Singapore Journal of Stock Exchange, June, 6-13.

Thompson, H.E. and Wong, W.K., 1991, On the Unavoidability of 'Unscientific' Judgment in Estimating the Cost of Capital, Managerial and Decision Economics, 12, 27-42.

Tiku, M.L., Wong, W.K., Vaughan, D.C. and Bian, G., 2000, Time Series Models with Non-normal Innovations: Symmetric Location-Scale Distributions, Journal of Time Series Analysis, 21(5), 571-596.

Wan, H. and Wong, W.K., 2001, Contagion or Inductance: Crisis 1997 Reconsidered, Japanese Economic Review, 52(4), 372-380.

Wang, K.Y., Li and Erickson, J., 1997, A New Look at the Monday Effect, Journal of Finance, 52, 2171-86.

Wong W.K., Chew, B.K. and Sikorski, D., 2001, Can P/E Ratio and Bond Yield be used to beat Stock Markets? Multinational Finance Journal, 5(1), 59-86.

Wong, K.A. and Ho, H.D. 1986 The Weekend Effect on Stock Returns in Singapore, Hong Kong Journal of Business Management, 4, 31-50.

Wong, K.A., Kui, T.K. and Chan, C.Y., 1992, Day-of-the-Week Effects: Evidence from Developing Stock Markets, Applied Financial Economics, 2, 49-56.

Wong, W. K. and Bian, G., 2000, Robust Bayesian Inference in Asset Pricing Estimation, Journal of Applied Mathematics \& Decision Sciences, 4(1), 65-82.

Wong, W.K. and Chan, R., 2004, The Estimation of the Cost of Capital and its Reliability, Quantitative Finance, 4(3), $365-372$.

Wong, W.K. and Li, C.K., 1999, A Note on Convex Stochastic Dominance Theory, Economics Letters, 62, 293-300.

Wong, W.K. and Miller, R.B., 1990, Analysis of ARIMA-Noise Models with Repeated Time Series, Journal of Business and Economic Statistics, $8(2), 243-250$.

Wong, W.K., Manzur, M. and Chew, B.K., 2003, How Rewarding is Technical Analysis? Evidence from Singapore Stock Market, Applied Financial Economics, 13(7), 543-551. 